\title{
KINOLOGIJA BENDROJO UGDYMO MOKYKLOJE
}

\author{
Dainius Statkevičius \\ Kauno „Vyturio“ gimnazija, Lietuva \\ El. paštas: dainiukas0219@gmail.com
}

\section{Ivadas}

Šunys 15 tūkstančių metų yra neatsiejama visos žmonijos tiek gyvenimo, tiek kultūros dalis (Lobell ir Powell, 2010). Mokslas apie šunis vadinamas kinologija (kynos - šuo, logos - mokslas). Jis nagrinèja šunų kilmę, veisles, anatomiją, auginimą, dresavimą, šèrimą, parodų organizavimą ir kt. (lietuviužodynas.lt). Kitas dažnai vartojamas terminas yra kaniterapija - tai terapijos metodas, pagristas teigiamu žmonių ir šunų sąveikos poveikiu i fizinius, psichologinius ir socialinius žmonių aspektus. Šis metodas dažnai naudojamas įstaigose, užsiimančiose vaikų priežiūra ir švietimu (vaikų darželiuose, mokyklose, globos namuose), sveikatos priežiūros įstaigose, senelių namuose ir kitose specialiose įstaigose, turinčiose vaikų ir suaugusiųjų su jevairiais psichikos sutrikimais (Čepková \& Sasáková, 2015).

Kita svarbi sritis - vaikų sužeidimai, kuriuos sukelia šunys. Siekiant pašalinti šią problemą, užsienyje specialistai organizuoja jivairias prevencines programas, kuriose dalyviai gauna ne tik teorines žinias, bet ir išmoksta saugaus kontakto su šunimi taisykles ir igauna gilią asmeninę patirtį. Šiuo klausimu Šveicarijoje buvo atliktas tyrimas, kuris parodė, jog tokios programos turi esminę reikšmę vaiko ir šuns santykių vystymesi (Chlopčíková, 2015). Nustatyta, kad interaktyvūs ugdymo moduliai daro teigiamą j̇taką tikslinès populiacijos elgesiui. Kontaktinè švietimo forma vaikams suteikia nepakeičiamą patirti, padedančią sumažinti rizikingą elgesi kontakto su šunimi metu (Duperrex et al. 2009). Tačiau reikia nepamiršti, jog tokiose mokymo programose ir kitose veiklose gali dalyvauti tik specialiai tam apmokyti šunys, pvz. kaniterapinis šuo, šuo vedlys ir kt. (Chlopčíková, 2015).

Kiti atlikti tyrimai parodė, kad gyvūnai vaidina gyvybiškai svarbų vaidmeni vaikų gyvenime ir kad sąveika su augintiniais prisideda prie savęs suvokimo, vaizduotès, žaidimo, empatijos ir moralès jausmo ugdymo. Be to, gyvūnai vaidina svarbų vaidmeni vaiko socialiniame ir komunikaciniame ugdyme, kurio tèvai ar mokytojai dažnai gali nesugebėti suteikti, nes vaikai ir gyvūnai dažnai sąveikauja kitaip nei suaugusieji ipratę (Solomon, 2010). Ypatingai bendraujant su šunimis vaikams yra svarbu tai, kad šunys mūsų neteisia, nekritikuoja, jei būna ištikimi ir nesiginčija, jie guodžia ir saugo (Fogle 2002). Tyrimai parodè, kad užsièmimuose su šunimis, vaikai gali lengviau susikaupti, padideja jų žaismingumas, pagerèja socializacija. Tačiau reikia paminèti, jog toks efektas nebuvo gautas su žaislais ar žaisliniu šunimi (Nedzinskaitè ir kt., 2019). Šunys ir kiti gyvūnai, kaip komunikabilūs partneriai, bendraudami ir prieidami prie vaiko suteikia vaikams jausmą, kad jie yra svarbūs, o tai pagerina vaiko emocinę būsena bei jo savivertę (Solomon, 2010). 


\section{Vykdomos veiklos mokykloje susijusios su kinologija}

Siekiant mokinius supažindinti su kinologijos pagrindais, skatinti kaniterapiją, labdarą, socialinę veiklą Kauno „Vyturio“ gimnazijoje organizuojamos ivairios veiklos, siekiant ịtraukti kuo daugiau mokinių. Ši veikla taip pat integruojama i ilgalaikį respublikinį projektą „Darni mokykla“.

\section{1 paveikslas}

Kinologijos specialistès ir veisejos
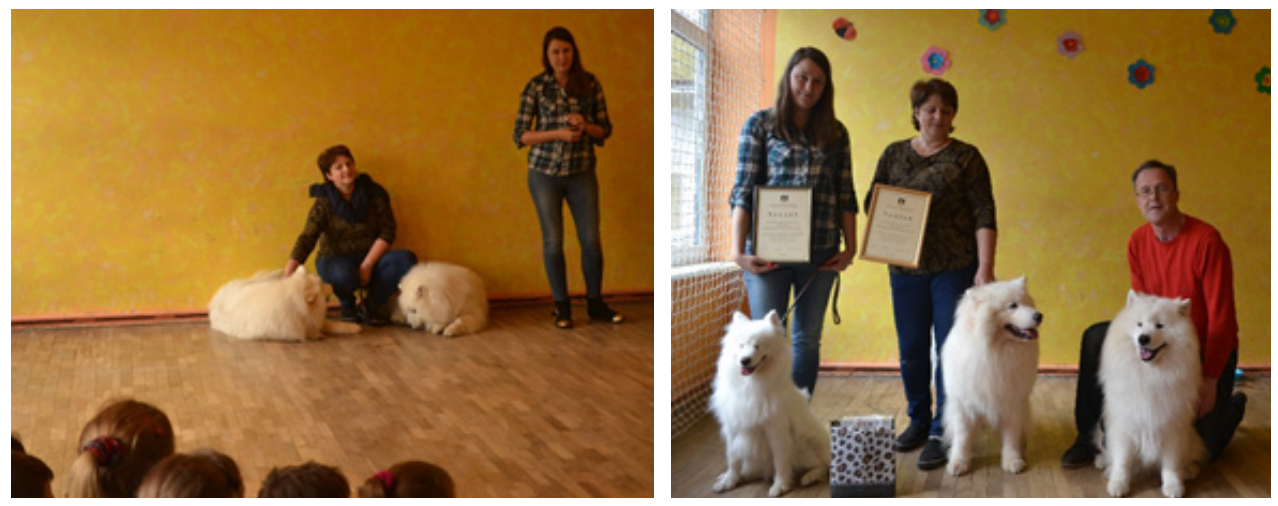

2018 m. pavasari pradinių klasių mokiniams buvo organizuotas edukacinis užsièmimas „Ar moki elgtis su šunimis“. Užsièmimą vedè kinologijos specialistès ir šunų veisèjos Dalia Mickienè ir Skaistè Skibiniauskienè, užsiemime dalyvavo ir trys samojedų veislès šunys (1 pav.).

Šio užsièmimo metu mokiniai buvo supažindinti su samojedų veisle, išmoko kaip prieiti prie nepažjstamo šuns, kaip elgtis, jei netikètai užpuola nepažjstamas šuo. O užsiemmimo pabaigoje dalyvavo ir mini kaniterapijos seanse, kurio metu galèjo gyvai pabendrauti ir paglostyti šunis (2 pav.). Būtina akcentuoti, kad panašaus pobūdžio užsiemmimuose gali dalyvauti tik specialiai apmokyti šunys bei jų vedliai, o mokytojams būtina pasirūpinti tèvų sutikimais, kur pažymima, kad vaikai neturi alergijos šunims. Tokio užsièmimo nauda yra didelè, jau pirmo užsièmimo metu keli mokiniai išsigydè baimę šunims. 


\section{2 paveikslas}

Užsiemimai su šunimis
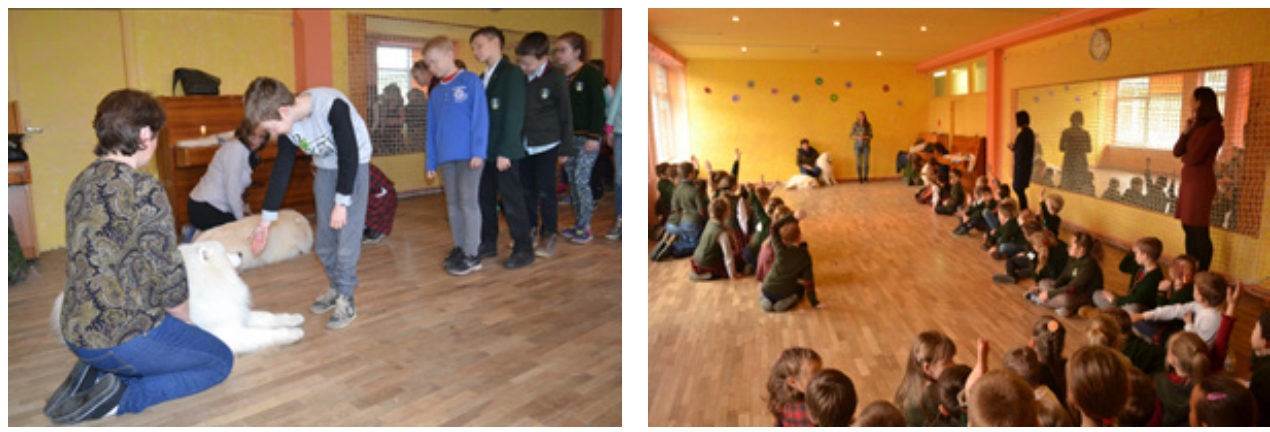

Nuo 2018 m rudens pradètos organizuoti socialinès akcijos „Parems beglobius", skirtos Pasaulinei gyvūnų globos dienai. Šių akcijų metu gimnazijos bendruomenè renka paramą beglobiams šunims gyvūnų prieglaudoje. Renkamas sausas pašaras, konservai, pavadèliais ir kitas inventorius. Akcijos partneris beglobių gyvūnų prieglauda VŠl „Penkta koja“, o akcijos simbolis biologijos mokytojo šeimos samojedų veislės šunys Striker ir Bona, kurių visas parodose laimètas sausas pašaras skiriamas beglobiams (3 pav.). Taip skatinamas mokinių sąmoningumas, labdaros teikimas bei socialinè veikla ir atsakingumas. Nes už visus beglobius, esančius prieglaudose yra atsakingi žmonès.

\section{3 paveikslas.}

Socialiné akcija "Parems beglobius"

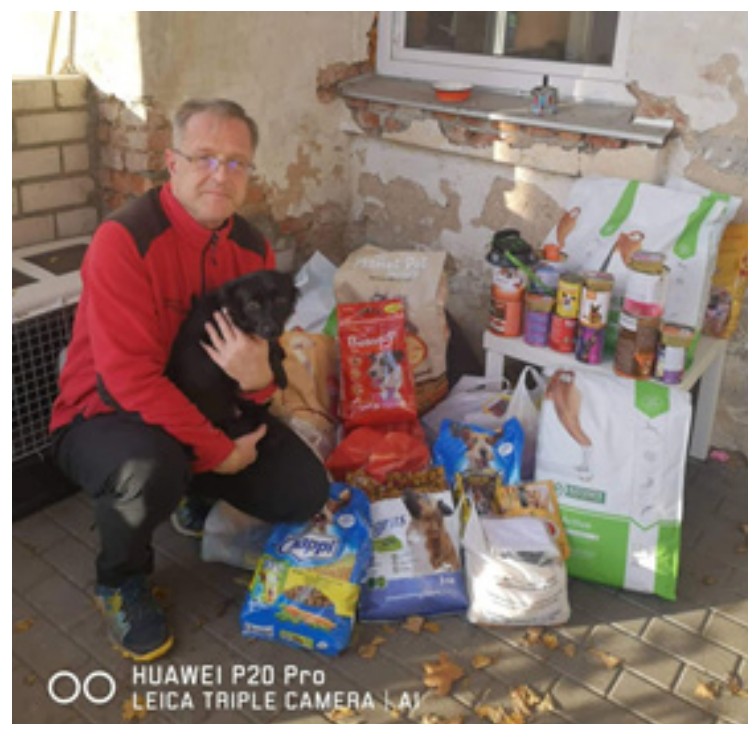


2019 m. pavasari buvo organizuotas integruotas projektas „Panaudok atliekas ir padèk beglobiams“. Šio projekto metu buvo siekiama skatinti gimnazijos bendruomenę tausoti aplinką, rūšiuoti atliekas, atliekų antrini panaudojimą, labdarą. 6-7 klasių mokiniai technologijų pamokų metu iš tekstilès atliekų gamino pavadèlius, antkaklius, žaislus šunims. Visi dirbiniai buvo eksponuojami mini parodoje ir pristatyti beglobiams VŠl „Penkta koja“. Tikimasi, kad tai nebus vienkartinis projektas ir taps gimnazijos tradicija.

2020 m. vasario mèn. gimnazijoje organizuotas protmūšis „Ar pažisti šunis ir jų veisles“. Mokiniai galèjo susipažinti ne tik su šunų veislėmis, bet ir jų kilme, paskirtimi ir įdomiais faktais. Protmūšyje dalyvavo 8-II gimnazijos klasių mokiniai.

Planuojama tęsti šias veiklas, tuo pačių planuojamos ir naujos veiklos. Nuo 2020 m. rugsèjo mènesio planuojamas pasirenkamas dalykas III-IV gimnazijos klasių mokiniams „Kinologijos pagrindai“. Šio kurso metu planuojama mokinius supažindinti su šuns anatomija, pagrindinèmis ligomis, bei veislèmis, jų kilme, paskirtimi, šunų parodų organizavimu. Taip galima organizuoti akciją pradinių klasių mokiniams "Skaitau šuniui“. Jos tikslas padèti sunkiau skaitantiems mokiniams jveikti ši trūkumą. Nes skaitydamas šuniui, vaikas atsipalaiduoja, šuo neduoda pastabų, nekritikuoja, nebara. Tokiam užsièmime dalyvauja tik vaikas, šuo ir šuns vedlys. Nei mokytojas, nei tèvai dalyvauti negali.

\section{Apibendrinimas}

Apibendrinant būtina paminèti, kad visos veiklos susilaukia didesnio ar mažesnio mokinių susidomėjimo. Ypač jos svarbios pradinių klasių mokiniams. Taip pat siekiama ir akcentuojama, kad žmogus norèdamas auginti tam tikros veislès šuni, privalo kreiptis į veislyną, o norèdamas auginti tiesiog šunį - i prieglaudą.

\section{Literatūra}

Čepková, K., \& Sasáková, N. (2015). Interconnection of canis therapy and art therapy. Folia, 59(2), 148-152.

Chlopčíková, M. (2015). Interactive education-preventive programme as efficient prevention means for contact of children and dogs. Journal of Nursing, Social Studies, Public Health and Rehabilitation, 1, 2, 55-67.

Duperrex, O., Blackhall, K., Burri, M., \& Jeannot, E. (2009). Education of children and adolescents for the prevention of dog bite injuries. Cochrane Database of Systematic Reviews, (2). https://doi.org/10.1002/14651858.CD004726.pub2

Fogle, B. (2002). Šunys. Enciklopedija [Dogs. Encyclopedia]. Alma littera.

Lietuvių žodynas, [interaktyvus]. https://www.lietuviuzodynas.It/terminai/Kinologija

Lobell, J. A. \& Powell, E. (2010). More than man's best friend. Archeology, 63(5). https://archive.archaeology.org/1009/dogs/

Nedzinskaitè, U., Mažeikaitė, J., Paleckaitis, M., \& Stankevičius, R. (2019). Canine-assisted therapy and the improvement of physical characteristics in disabled children: A pilot study. Sveikatos mokslai=Health Sciences in Eastern Europe, 29(6), 88-94. https://doi.org/10.35988/sm-hs.2019.106 
Solomon, O. (2010). What a dog can do: Children with autism and therapy dogs in social interaction. Ethos, 38(1), 143-166. https://doi.org/10.1111/j.15481352.2010.01085.x

\section{Summary}

\section{CINOLOGY IN A GENERAL EDUCATION SCHOOL}

\section{Dainius Statkevičius}

Kaunas „Vyturys" Gymnasium, Lithuania

Dogs for 15,000 years have been an integral part of all humanity in our life and culture. In recent times, canitherapy has gained in popularity as a therapeutic approach based on the positive effects of human-dog interaction on the physical, psychological and social aspects of humans. This method is often used in institutions for child care and education (kindergartens, schools, care homes), health care facilities, retirement homes and other special facilities for children and adults with various mental disorders. In order to introduce pupils to the basics of cynology, to promote canitherapy, charity and social activities, various activities are organized at Kaunas Vyturys Gymnasium in order to involve as many pupils as possible. This activity is also being integrated into the long-term project "Sustainable School". It is also sought and emphasized that a person must go to a kennel if he wants to have a certain breed of dog, but if he wants to have dog (does not matter breed), he must go to a shelter. This way is to combat breeding of undocumented breeding dogs. The gymnasium organizes educational classes with dogs for primary school learners, social campaigns "Support the homeless", integrated project "Use waste and help the homeless", quizzes "Do you know dogs and their breeds". Also it is planned to prepare an elective subject for students of grades 11-12 "Basics of Cynology".

Keywords: cynology, canitherapy, social activity, education with dogs. 